\title{
The Predicaments of Language Learners
}

\section{in Traditional Learning Environments}

\author{
Latisha Asmaak Shafie (Corresponding author) \\ Academy of Language Studies, Universiti Teknologi MARA Perlis \\ 02600 Arau, Perlis, West Malaysia, Malaysia \\ Tel: 60-16-531-8095Ｅ-mail: ciklatisha@perlis.uitm.edu.my
}

Mahani Mansor

Academy of Language Studies, Universiti Teknologi MARA Perlis

02600 Arau, Perlis, West Malaysia, Malaysia

Tel: 60-12-438-3480Ｅ-mail: mahani@perlis.uitm.edu.my

\begin{abstract}
Some of public universities in developing countries have traditional language learning environments such as classrooms with only blackboards and furniture which do not provide conducive learning environments. These traditional environments are unable to cater for digital learners who need to learn with learning technologies. In order to create conducive language learning environments for digital learners, it is imperative to understand the ways digital learners learn at public universities. This knowledge enables public universities to provide appropriate learning environments for digital learners so that they will be able Knowledge Workers. The paper investigates the effective language learning of digital learners at public universities. Furthermore, this paper discusses suggestions to construct these traditional language learning environments to effective language learning environments for digital learners.
\end{abstract}

Keywords: Traditional learning environments, Public universities, Digital learners

\section{Introduction}

It is a norm in most classes to find learners doodling, playing games and fiddling with their mobile phones, whispering to their friends and simply looking bored. On the contrary, they look vibrantly alive when the lesson ends. When tested on their understanding of the lesson, most of them face difficulties with higher-order thinking tasks. Will they be prepared to be global knowledge workers?

Learning theories, instructional methods and technologies revolutionize higher education in the Digital Age. Nevertheless, in developing countries, some of the public universities retain traditional learning environments such as classrooms and lecture halls only equipped with whiteboards and OHP projectors which are totally in conflict with the new knowledge. According to Bransford (2000) and Weigel (2002), the designs of these learning environments only support traditional oral content delivery via lectures which discourage learner-centered engaged learning. Physical environments like classrooms discourage active learning as physical characteristics of learning environments influence learners' cognition and behavior as conducive environments facilitate learning.

Teaching in the Digital Age is no longer telling and learning is no longer listening (Kop et al, 2004). Yet, in most public universities, faculty members teach in a two-hour lecture. During lectures, learners cram the information by memorizing and recalling information rather than utilizing advanced higher-order thinking which causes learners to fail to complete higher-order thinking tasks (Lemke, 2003; Weimer, 2002). Unlike learners at private universities, learners of public universities have limited facilities and possess historic classrooms to be shared with a large number of learners. These universities have many traditional classrooms with only white boards and OHP projectors, few laboratories and a few technology-enhanced rooms which are to be shared with thousands of students and hundreds of faculty members. Goolam Mohamedhai, the then Vice Chancellor of University of Mauritius (2002) in his speech on how globalization affects higher education in developing countries worries about the social gap between students from public universities and students of private universities. He stresses on the importance of funds which are needed by the public universities to have adequate resources and retain good faculty and satisfactory academic facilities for teaching and research. 
The ideal learning environments for digital learners are rich learning environments that enable and support learners to learn independently and collaboratively, regardless of their preferred learning styles. Learners have sophisticated classrooms to support e-learning and skills training activities which activities can be archived for later reference. Learners have personal computers that have a wide bandwidth high-resolution network connection, full-motion imaging and video streaming to and from the video server system, digital media, digital video, collaborative video conferencing, cameras and microphones. Thus, learners experience learning in new and diverse formats. Furthermore, learners and faculty members are able to collaborate in more authentic ways. These learning environments are usually found in private universities which differentiate learning in private universities and public universities. Failing to foster this kind of learning needed by digital learners would fail to prepare them to be able knowledge workers. Thus, it is imperative to foster the kind of learning needed in the Digital Age. The objectives of this paper were to investigate the effective language learning ways of digital learners at public universities and to add suggestions to construct these traditional language learning environments to effective language learning environments for digital learners.

\section{Literature review}

Future knowledge workers will have no assurance of predictability or simplicity. As future knowledge workers, they need to recognize and understand hidden patterns by forming connections between sources of information and creating useful information patterns with the help of distributed learning networks and communities of practice. In the Digital Age, learners are responsible for their own learning. Learners need more than listening, writing, memorizing and recalling as they assume the roles of investigators, researchers, thinkers and problem solvers. Siemens (2005) proposes that there are many significant trends in learning in the Digital Age. Many learners are expected to change their careers into different professions in their lifetimes, so informal learning will play a major role in learning. Hence, it is imperative to treat organizations and individuals as learning organisms. Siemens (2005) emphasizes that learning in the Digital Age occurs outside of learners' primary knowledge and within the organizations. So learners need to recognize, evaluate and synthesize connections, patterns and knowledge. By involving themselves in communities of practice or groups of practitioners, learners share information and develop their expertise in a particular domain of knowledge.

Seely Brown and Duguid (1996) emphasize that communities are the actual creators and conveyors of knowledge that enrich learning for university students. Digital learners need community as they learn by sharing and figuring out ideas with others. Learning for digital learners is through collaborative efforts (Layton, 2000). Brown (2002) suggests that learners learn from situated learning. A lot of learning depends on distributed intelligence which is resulted from situated learning and cognitive apprenticeship. An effective learning technique for digital learners is group studies where members depend on each other to interpret meanings. This method of learning supports the constructivism approach that argues that people learn best by doing as opposed to by taking instructions from others (Tapscott, 1998). Learners will be more involved and enthusiastic in learning if they could learn by their own "discovery".

By taking an active part in the learners' own learning, learners have a sense of ownership and commitment to learning process and learning will be more meaningful to them as it increases learners' autonomy (St. Louis, 2006). St. Louis (2006) cites autonomous learning as the ability to control one's learning (Holec, 1981) and the learners' psychological relations to content and process of learning, their capacity for critical reflection, detachment, decision making, and independent action (Little, 1991). Salaberry (2001) emphasizes on the ability of technology in enabling instant and individualized feedback in language learning as recent technologies are contextualized.

Thinking and learning in the Digital Age are defined and shaped by technology. Due to vast information, the ability to look for knowledge is vital for digital learners. By understanding the reality of knowledge workers, learning at higher education must prepare learners to be productive knowledge workers by including technologies in the curricula such as the inclusion of multiliteracies curriculum (The New London Group, 1996). Digital learners expect learning is as a series of active, interesting, fun activities and has instant gratification. So, when they encounter traditional learning environments and traditional learning instructions, they switch off their learning mode. Layton (2000) states, "Digital children are more independent, more intellectually open, more tolerant, and more adventurous than most $20^{\text {th }}$-century children. They hold strong views and expect instant gratification." The instant gratification that these digital learners want cannot be accommodated by traditional learning settings.

Gee (2003) advises educators to learn from video games designers in capturing the learners' interest by employing several strategies such as a context with necessary information, tasks given to learners are within the range of their capabilities, tasks that require creative problem solving and learners learn to use their sense and emotions through empathy towards virtual characters in the games. Dede (2005) believes that with the existence of multi-user virtual environment (MUVE), 'neo-millennial' learning styles will influence learning in the Digital Age. Based on "mediated immersion," these learning styles include multiple media fluency which requires learning through collectively seeking, sieving and synthesizing experiences. It emphasizes on active learning through real and stimulated experiences which require frequent opportunities for reflective learning. 


\section{Suggestions for learning for digital learners in traditional environments}

It is imperative to ensure learning at public universities accommodate the current learning styles of digital learners. The following are several suggestions on how to foster engaged learning and how to turn these traditional learning environments to enriched learning environments that are conducive for digital learners.

\subsection{University Level}

It is imperative that public universities regard themselves as learning organizations. Therefore, the climate for life-long learning must be supported and fostered by encouraging the faculty members, staff and students to participate in any learning activities that promote life-long learning such as collaborations and researches. Public universities must encourage informal learning through involvement of distributed learning networks, communities of practice and other technology-enhanced collaborative learning environments within universities and other universities.

\subsubsection{Be innovative in the use of technology}

Public universities must be innovative in the use of technology as they are educating technology-savvy learners. In order to use technology effectively in teaching and learning, public universities need to invest in people (faculty, staff and students) and technologies. Staff should be sent for trainings to use the latest technological gadgets and students should be involved in tasks that require them to use the latest technologies. In relation to that, public universities need to include their students' feedback on the effective ways to educate these digital learners. In addition, public universities need to utilize their existing technologies and the traditional teaching approaches to design new instructional methods and new curricula for their learners. Public universities must have comprehensive technology plans to incorporate technologies into curricula. This is done by training high-level digital fluencies like multimedia graphic designs, general computing concepts, information literacy, word processing, presentations, spreadsheets, database management and web authoring to staff and faculty members. In addition, faculty members should be provided with consulting services in implementing technology in their classes.

\subsubsection{Emphasize on the libraries and digital libraries}

Public universities must ensure that their libraries and digital libraries are the souls of their learning communities. Libraries of the public universities could collaborate and share online resources. When information and resources are pooled, libraries can become a common access-point to learning materials. Thus, faster and more efficient access to information can be made. The role of libraries is not only as collectors of resources but also more that of a knowledge navigator or a facilitator of retrieval and dissemination of information and resources.

\subsubsection{Provide e-learning spaces}

Public universities must provide more learning spaces for learning communities such as providing wireless networking environment to encourage active learning. The bandwidth of communications should be increased by increasing the internet access to off-campus resources and intranet capability so that faculty, staff and students can be connected together. On the other hand, public universities can collaborate with private universities as private universities have sophisticated learning spaces and technologies, while the private universities can utilize the expertise and experiences of the public universities.

\subsubsection{Develop Personal Learning Environments (PLE)}

Public universities must develop Personal Learning Environments (PLE) that enable learners to reap benefits of learning in the digital era; a learning which is life-long, informal and accommodate different styles of learning. Learners learn with one another yet they manage their own learning as they participate, integrate and contribute to their growth as learners. Public universities must revamp their assessments and evaluation. It is unfair to evaluate digital learners on their performance in traditional assessments such as paper-based assessments. Assessments should be treated as tools of learning that enable learners to learn better and foster love towards learning.

\subsubsection{Implement generic benchmarking}

Public universities should investigate the feasibility of using generic benchmarking instead of competitive benchmarking with direct competitors such as other universities. Generic benchmarking involves organizations which are indirect competitors but share similar procedure, practice and culture (Doerfel and Ruben, 2002). By benchmarking other successful private practices results in public universities becoming more competitive and relevant to their students and workforce. Thus, the policy makers of public universities need to identify potential successful practices and strategies to implement generic benchmarking in their organizations.

\subsection{Faculty Members}

\subsubsection{Implement collaborative teaching}

Collaborative teaching among faculty members must be encouraged as the faculty members learn to take risk and grow wiser. Faculty members could teach different components of the same subject or teach the same subject together. 
Learners learn the importance of collaboration from their lecturers as collaboration is the essence of learning in the Digital Age.

\subsubsection{Implement collaborative learning}

Collaborative learning among university undergraduates promotes authentic learning as knowledge workers collaborate with others when they work. By simulating an event that resembles an authentic situation, learners not only learn decision-making and evaluating skills, but they also indirectly learn about culture and society. Spelleri (2002) states that junk mails, coupons, store advertisements and flyers are cultural information about society which enables learners to learn more about the society. Hence, instructors at public universities may be able to manipulate these materials which are rich in cultural content for their teaching materials. Collaborative activities in designing flyers for a particular activity in the campus require communicative skills, thinking skills, problem-solving skills and writing skills. Further activities such as digital storytelling could be used to document the process of the project and the report is disseminated through printed media and digital content in forms of mms or e-mail.

\subsubsection{Foster collaboration across disciplines}

Fostering collaboration across disciplines such as interdisciplinary teaching must be implemented as the learners are aware of the connections of the different disciplines. In language teaching, instructors need to integrate technical terms of a field with the general vocabulary of English. For example, English is taught to future accountants by teaching the technical terms used in Accountancy which determine the relevancy of English.

\subsubsection{Encourage learners to utilize their gadgets}

Learners should be encouraged to utilize their gadgets like hand phones with cameras, videos and laptops in their learning activities to improve language learning. In teaching about environmental awareness in a language class, an instructor may instruct learners to use their gadgets to create digital content blogs, podcasts, digital storytelling or electronic portfolio as evidence of their understanding. Moreover, learners may be able to utilize their handheld devices such as their phones to download mobile dictionaries.

\subsubsection{Design stimulating lessons}

Lessons should be designed to motivate learners by understanding their extrinsic and intrinsic motivating factors. Authentic materials such as job interviews and meetings can be used to encourage them to learn. The context and content must be relevant to learners. In addition, learning activities should consist of multi-step tasks that have intrinsic feedback and delay judgment. Instructors can manipulate technology for entertainment like video game consoles to provide interactive contents to the learners such as 'Who Wants to be a Millionaire.'

\subsubsection{Assume less traditional roles}

Faculty members should assume less traditional roles as they are no longer knowledge dispenser but knowledge architect and designers (Kopp et al., 2004). Instructors need to revolutionize the teaching and learning practice by becoming actively involved as facilitators who teach learning strategies on learning unfamiliar content. They should also be independent learners of media and information fluency as they are invaluable skills for the 21 st century knowledge workers. By training learners to possess digital fluency, it would enable learners to manipulate technological tools to construct meaning and understanding of their learning. For instance, instructors should train students to write in weblogs instead of journals. In addition, learners need to be given the opportunities to construct their podcasts or vodcasts instead of oral report. They too should be encouraged to do digital storytelling instead of traditional storytelling and participate in simulated worlds in Second Life. These activities may improve the faculty members' technological, media and information fluency. It should be stressed that in order to teach these digital learners, instructors need to constantly improve these skills.

\subsubsection{Involve actively in social networking sites}

Faculty members should be actively involved in social networking sites such as Facebook, MySpace and Friendster with their peers and learners. They need to be familiar and creative with the technological tools and different types of media and they should also be able to interpret different types of information (Jukes, 2004).

\subsubsection{Implement tutoring system (Peer Teaching)}

Tutoring system (Peer Teaching) among learners should be implemented as by teaching the others, it is the faster way to understand a concept. In order to teach, learners need to plan their teaching which requires them to revise and check their own understanding. Hence, they understand the subjects better. By presenting their own independent learning to their peers, it would enable them to enhance not only their confidence in their learning but also their communicative skills. 


\subsubsection{Provide training to learners}

Learners should be provided with trainings like digital video production, website design, online research, information analysis with spreadsheets and databases and networking. The trainings enable learners to prepare themselves with the reality of their present learning styles and future workplace demands. Such learning provides engaging learning environments to the learners and at the same time increases their employability skills.

\section{Conclusion}

Keeping abreast with the latest technology outside the classroom and implementing it inside the classroom is a challenge to some public universities as they need to equip learners with knowledge that they need to face the reality of working world upon graduation. The recent trend indicates that universities are no longer providers of knowledge but as purveyors to knowledge. As Resnick (2002) points out, “... we need to transform curricula so that they focus less on "things to know" and more on "strategies for learning the things you don't know." As new technologies continue to quicken the pace of change in all parts of our lives, learning to become a better learner is far more important than learning to multiply fractions or memorizing the capitals of the world." As for public universities, adaptation to the latest technologies should be made by utilizing the existing technology, the current traditional settings and the community so that learners gain the reward of a life-long learning.

\section{References}

Bransford, J., Brown, A., Cocking, R. (Eds). (2000). How People Learn: Brain, Mind, Experience and School. Washington, D.C.: National Research Council.

Brown, S. J. and Duguid, P. (1996). The University in the Digital Age. Change: July-August,10-19.[Online]Available: http://www.sociollifeinformation.com/U_in_Digital_Age.htm. (May 24,2007)

Dede, C. (2005). Planning for "neomillennial" learning styles: Implications for investments in technology and faculty. In J. Oblinger \& D. Oblinger (Eds.), Educating the net generation . Boulder, CO: EDUCAUSE Publishers.pp 226-247.

Dick, W.and Carey, L.,Carey , J. O. (2001). The systematic design of instruction (5th ed.). NY: Addison-Wesley.

Doerfel M. and Ruben, B. (2002). Developing More Adaptive, Innovative, and Interactive Organisation.In Bender, B and Schuh, H. (Eds.), Using Benchmarking to Inform Practice in Higher Education, New Directions for Higher Education, No. 118. Jossey Bass, San Francisco.

Gee, J. P. (2003). What Video Games Have to Teach Us About Learning and Literacy. New York: Palgrave/Macmillan.

Goolam Mohamedhai. (2000). Internalization of Higher education. [Online] Available: http://www.unesco.org/iau/conferences/china/pdf/IAU_Internat_Conf_00_Goolam_Mohamedbhai.pdf. (April 20,2007).

Holec, H. (1981). Autonomy in Foreign Language Learning. Oxford: OUP.

http://www.iatefl.org.pl/call/j_esp25.htm (May 28, 2007).

Jukes, I. (2004). Closing the Digital Divide: The Seven Things Education and Educators Need to Do. [Online] Available:from http://web.mac.com/iajukes/thecommittedsardine/Handouts_files/ctdd.pdf (September 15,2008).

Kopp, S., Stanford, L. , Rohlfing, K. \& Kendall, J.(2004).Creating Adaptive Learning Environments .Planning for Higher Education,32(2), 12-23.

Layton, Thomas G. (2000). Digital Learning: Why tomorrow's schools must learn to let go of the past.[Online] Available: From http://www.electronic-school.com/2000/09/0900f1.html ( June 12,2007).

Lemke, C. (2003). Standards for a modern world: Preparing students for their future. Learning \& Leading With Technology, 31, 6-9.

Little, D. (1991). Learner Autonomy. 1: Definitions, Issues and Problems. Dublin: Authentik.

Mettam, G. R. \& Adams, L. B. (1994). How to prepare an electronic version of your article. In B. S. Jones, \& R. Z. Smith (Eds.), Introduction to the electronic age. New York: E-Publishing Inc. pp. 281-304.

New London Group. (1996). A pedagogy of multiliteracies: Designing social futures. Harvard Educational Review, 66(1), 60-92.

Prensky, M. (2001). Digital Natives Digital Immigrants.[Online] Available: From http://www.marcprensky.com/writing/Prensky\%20-\%20Digital\%20Natives,\%20Digital\%20Immigrants\%20-\%20Part1. pdf ( September 15,2008).

Pullchino, J. (2006). Mobile Learning Research Report.The E-learning Guild. [Online] Available: From http://www.elearningguild.com/ (July 11, 2007). 
Quintero, Linda J. Castaneda. (2007). Impelementing online resources in face-to-face university contexts. The students' perspective. [Online] Available: From http://www.elearningpapers.eu (April 23,2007).

Resnick, Mitchel. (2002) .Rethinking Learning in the Digital Age. [Online] Available: From http://www.cid.harvard.edu/cr/pdf/gitrr2002_ch03.pdf (December 10, 2007).

Salaberry, M. R. (2001). The Use of Technology for Second Language Learning and Teaching: A Retrospective. The Modern Language Journal, 85(1), 39-56.

Seppala P. \& Alamaki H. (2003). Mobile Learning in Teacher Training. Journal of Computer Assisted Learning ,19(3), 330-335.

Sharples, M., Jefferey, N., Du Boulay, J.B.H., Teather, D., Teather B. \& Du Boulay, G.H. (2002). Socio-cognitive engineering: a methodology for the design of human- centred technology. European Journal of Operational Research, 136:310-323.

Shih, Y. E. (2005). Seize Teachable and Learnable Moments: SMSE instructional design model for mobile learning. Paper presented at the International Mobile Learning 2005.

Siemens, G. (2005). Meaning making, learning, subjectivity. [Online] Available: From http://connectivism.ca/blog/2005/12/meaning_making_learning_subjec.html (November 12, 2006).

Smith, Joe. (1999). One of Volvo's core values. [Online] Available: http://www.volvo.com/environment/index.htm (July 7, 1999)

Spelleri, Maria. (2002). "From Lessons to Life: Authentic Materials Bridge the Gap. ESL Magazine (March/April 2002).[Online] Available : From http://www.eslmag.com/modules.php?name=News\&file=article\&sid=18 (May 26,2007).

St. Louis, Rubena. (2006). Helping Students Become Autonomous Learners: Can Technology Help?. Teaching English with Technology. A Journal for Teachers of English, 6(3). [Online] Available: From http://www.iatefl.org.pl/call/j_esp25.htm (May 28,2007).

Strunk, W., Jr., \& White, E. B. (1979). The elements of style. (3rd ed.). New York: Macmillan, (Chapter 4).

Tapscott, Don. (1998) .Growing Up Digital:The Rise of the Net Generation.[Online] Available: From http://www.ncsu.edu/meridian/jan98/feat_6/digital.html (January 15,2009).

Taylor,J., Sharples, M., O’Malley , C., Vavoula, G., \& Waycott,J. (2006). Towards a Task Model for Mobile Learning: a Dialectical Approach.Accepted for publication in International Journal of Learning Technology.

Van der Geer, J., Hanraads, J. A. J. \& Lupton R. A. (2000). The art of writing a scientific article. Journal of Scientific Communications, 163, 51-59.

Weigel, Van B. (2002). Deep learning for a digital age: Technology's untapped potential to enrich higher education. San Francisco: Jossey-Bass. 